\title{
Encounters and the photographic record in British New Guinea
}

\section{Antje Lübcke}

The intricacies of encounters between photographers and their subjects need to be examined more closely, especially in the colonial context, as it has too often been taken for granted that the photographer was solely responsible for the resulting image or the only agent in the photographic encounter. The cameras that were used and the associated materials and chemicals needed for photography in the late nineteenth century meant that setting up a shot and developing a photograph were neither simple nor quick tasks. European photographers who travelled to the newly acquired territories of empire relied on local carriers and interpreters to assist them in their work; and when it came to photographing the indigenous people of these lands, the photographic encounter was shaped to varying degrees by their willingness to be photographed. Just as Felix Driver and Lowri Jones assert that 'exploration was a joint project of work' and a 'shared experience', ${ }^{1}$ I argue that the practice of photographing foreign lands and indigenous peoples was similarly dependent on local expertise and participation for its success.

In this chapter I examine a series of photographic encounters in southeast New Guinea in the late nineteenth century - in 1885 to be precise. These encounters were between the Melbourne-based professional photographer

$1 \quad$ Driver and Jones 2009: 11, 5. 
John William Lindt and the Papuans of British New Guinea. In particular, I am interested in how the Papuans Lindt photographed influenced the nature of the encounter and the resulting image, and in the mediating role played by the missionary Reverend William G. Lawes of the London Missionary Society (LMS). Further, I argue that Lindt's camera can also be understood as an historical actor or agent in photographic encounters. The cultural and social values and meanings attached to the camera in the late nineteenth century and its mere physical presence, often significantly influenced the interactions that took place. Both sides of the photographic encounter are investigated, and while my analysis relies primarily on the visual and textual documents created by Lindt and other Europeans, by critically examining these sources and considering the concomitant conditions that shaped these particular encounters, a more nuanced picture emerges that allows the uncovering of indigenous people's agency.

\section{Lindt in New Guinea}

Johannes Wilhelm Lindt came to Australia from Germany in 1862 at the age of $17 .^{2}$ A romantic, middle-class, educated youth, he had run away to sea and worked his passage to Australia aboard a Dutch ship. After a time spent travelling in Australia, tuning and repairing pianos, Lindt settled in Grafton on the Clarence River in New South Wales, where he took up work as an apprentice for the artist and photographer Conrad Wagner in his photographic studio. There he received his photographic training, and after taking over the running of the studio in 1870 made his living producing carte-de-visite portraits and photographing subjects as diverse as horses and cattle, landscape views, and the local architecture. He also regularly undertook fieldtrips, lugging the cumbersome and fragile photographic equipment (including a portable darkroom) with him to visit outlying hamlets. On these trips he photographed local Australian Aboriginal people, capturing them on glass-plate negatives, and in 1873-74 he produced his famous series of around 60 tableaux portraits titled Australian Aboriginals. ${ }^{3}$ Lindt won several medals for his photographs in international exhibitions and following this success he moved to Melbourne in 1876 with his wife Anna (nee Wagner - the daughter of Lindt's former boss). It was not long before he opened his own studio on Collins Street, where he continued to sell his Clarence River portraits and views but also added to his catalogue by photographing the city that was now his home. ${ }^{4}$

\footnotetext{
2 Lindt became a naturalised British subject in 1869.

3 For discussions of Lindt's photographs, see Cato 1955: 70-75; Jones 1985; Newton 1988: passim; Orchard 1999; Poignant 1992: 56; Quanchi 2007: passim; Quartermaine 1992; Willis 1988: 86-90.

4 Jones 1985: 3-6.
} 
In early 1885 when, as Lindt writes, 'rumours of annexation [of south-east New Guinea] became rife', ${ }^{5}$ Reverend Lawes visited Melbourne while on deputation in the country and the two men discussed Lindt's dream of visiting the Pacific island that he had first sighted in 1868, on his return voyage from a visit to Europe.$^{6}$ It seems little further encouragement was needed for Lindt to set about turning his dream into a reality. He persuaded an influential friend and client, Sir Frederick Sargood, to introduce him to Sir Peter Scratchley. Scratchley was the first Special Commissioner of British New Guinea, which had been declared a Protectorate in a series of flag-hoisting ceremonies performed by Commodore John Elphinstone Erskine and the Australian Squadron in villages along the south-east coast in November 1884. Lindt convinced the Special Commissioner to allow him to join his expedition to New Guinea as its official photographer, and even secured darkroom facilities on board SS Governor Blackall for developing his glass-plate negatives. ${ }^{7}$ Undoubtedly, Lindt's reputation as a talented photographer of landscapes and cityscapes as well as his celebrated series of tableaux portraits of Australian Aboriginal subjects influenced the Commissioner's decision to allow Lindt to join the expedition.

Lindt arrived in Port Moresby at the end of August 1885 and remained in New Guinea for six weeks. (He was originally meant to stay for the full three months of the official expedition, but his wife took ill.) He returned to Melbourne at the end of October with approximately 128 exposed glass-plate negatives and subsequently made available for sale 124 of these (as prints) through his Collins Street studio. ${ }^{8}$ The complete set of 'Picturesque New Guinea' photographs was presented in five albums, and customers who visited Lindt's studio could select the images they preferred in a number of formats. Lindt chose to enlarge seven of the photographs to $48 \times 36$ inches for the explicit purpose of display in 'Libraries, Museums and Halls', and these could also be purchased, in oak frames, through his studio. ${ }^{9}$

\footnotetext{
Lindt 1887: ix.

Lindt 1887: viii.

Jones 1985: 11.

There are four views of Brisbane and Cooktown included in the 'Picturesque New Guinea' series.

Lindt 1888: 8. A complete set of Lindt's 'Picturesque New Guinea' albums is held at the State Library of Victoria (SLV) in Melbourne (LTA 156 - LTA 160, Pictures Collection). The Cambridge University Museum of Archaeology and Anthropology in the UK also has a complete set (G.2.1, A.1. - A.5. LDT, PNG), while individual albums containing a selection of images from the series are held at the SLV (H2009.46/1-12, Pictures Collection, SLV), the Mitchell Library in the State Library of New South Wales in Sydney (PXB 420), and the National Gallery of Australia in Canberra (acc. no.: 84.1484.1-25). The Mitchell Library also holds a complete set of the display-size prints (ML611), though these were taken out of their frames in July 1933, and the National Museum of Victoria (Museum Victoria) also has five carbon print enlargements of Lindt's New Guinea photographs, as well as two from his 'Picturesque New Hebrides' (1890) series, in its collections. Individual prints from the 'Picturesque New Guinea' series can be found in collections in the UK, Australia, New Zealand, Germany, the USA, and Switzerland. There are almost certainly more 'Picturesque New Guinea' prints in both public and private collections the world over.
} 
Taking advantage of the public interest generated in England and Australia around the acquisition of a new territory, Lindt dedicated his 'Picturesque New Guinea' series and the book of his travels that he wrote on his return to Melbourne to Queen Victoria. The book was also titled Picturesque New Guinea and contains 50 autotype reproductions of Lindt's New Guinea photographs. Further, Lindt enlarged, framed and put on display a selection of the images in colonial exhibitions in London (1886) and Melbourne (1888), where they were seen by the many visitors who attended these spectacles of empire. Around 5.5 million people visited the Colonial and Indian Exhibition in 1886, where photographs from England's far-flung territories were put on display alongside 'curios' and the marketable natural and cultural products of each country. ${ }^{10}$

It is clear that Lindt's image of New Guinea was conceived long before leaving Australian shores. Along with his preconceptions of what New Guinea must be like, based on his reading and encounters with the Italian naturalist-explorer Luigi Maria D'Albertis and Reverend Lawes, the fact that Lindt only had a set amount of time in New Guinea meant he likely had in mind a catalogue of views and subjects he wanted to capture. The subjects that appealed to Lindt, or at least those he selected for his 'Picturesque New Guinea' series, are diverse. They range from posed group portraits of 'native teachers', to more relaxed shots of expedition parties setting out from Port Moresby - though these are only seemingly 'relaxed', as the exposure times in early photography meant the subjects often had to remain motionless for long periods (depending on light conditions). Lindt also photographed the local landscapes and flora, including views of scrub, bush tracks, coconut groves, bays, beaches, and rivers, as well as the campsites of the expedition parties, village scenes and dwellings, material culture, stuffed birds of paradise, rituals and ritual structures, boats associated with the expedition and the mission, and the local sea craft. Jack Cato notes that it was Lindt's 'self-imposed task ... eventually to provide the British people with a magnificent panorama of life and conditions in this, the newest of Britain's protectorates' ${ }^{11}$ While many of the subjects Lindt photographed were likely dictated by the requirements of the official expedition, it is certainly an impressive list and shows Lindt's versatility in the field. Viewed as a whole, the 'Picturesque New Guinea' series represents a clear visual agenda on the part of the photographer. ${ }^{12}$

\footnotetext{
10 Barringer 1998: 23.

11 Cato 1952: 402.

12 Lindt was not the first professional photographer to travel to south-east New Guinea. Augustine Dyer accompanied Commodore Erskine's official expedition in 1884 in order to document the proclamation of the British Protectorate. John Paine also sold proclamation prints through his Sydney studio, though his photographs were taken by two petty officers on board HMS Espiegle (see Newton 1988: 58; Barker 2010: 99, 135).
} 
Aside from fulfilling the photographer's aesthetic and commercial requirements, the 'Picturesque New Guinea' series was intended to serve the purposes of the political and scientific expedition of which Lindt was a part. Lindt's motto had long been 'Truth - but Truth in a pleasant form' and, indeed, a key underlying narrative of Lindt's book is that of the professional artist-photographer as a valuable asset to the expedition. ${ }^{13}$ This is not surprising as the camera was employed in the service of science soon after its invention in 1839. It was believed it could faithfully record the countries and peoples that were being 'discovered' by European explorers. In the opening lines of the preface to Lindt's book he writes of his disappointment that, in the past, exploring expeditions had not chosen their artists and photographers with as much care as they selected the scientific staff, which acted to underscore the importance, at least in Lindt's mind, of his accompanying the 1885 expedition:

For years past, when perusing the account of exploring expeditions setting out for some country comparatively unknown, I always noticed with a pang of disappointment that, however carefully the scientific staff was chosen, it was, as a rule, considered sufficient to supply one of the members with a mahogany camera, lens, and chemicals to take pictures, the dealer furnishing these articles generally initiating the purchaser for a couple or three hours' time into the secrets and tricks of the 'dark art', or when funds were limited to purchase instruments, it was taken for granted that enough talent existed among the members to make rough sketches, which would afterwards be 'worked up' for the purpose of illustrating perhaps a very important report. ${ }^{14}$

Lindt was convinced he had succeeded in capturing scenes straight from 'savage real life' during his time in New Guinea. ${ }^{15}$ However, the 'reality' committed to the glass-plate negatives was mediated through the European photographer's perspective and preconceptions, and enhanced through the developing and printing processes employed in Lindt's studio, and the framing devices used in the subsequent display and reproduction of the images. The visual archive, like all archives, is partial. But this archive can also be read against the grain and alongside the textual archive to uncover the agency of local actors.

\section{Local agency in photographic encounters}

While Lindt left behind an archive of texts and images from which his perceptions and motivations may be inferred, such an archive does not exist for the other side of this cross-cultural encounter to the same degree. Polynesian and Papuan

13 Lindt 1883: 3. See also Lindt 1888: 5.

14 Lindt 1887: vii.

15 Lindt 1887: 44. 
teachers who worked for the LMS occasionally wrote letters to the organisation, and several travelled to Australia and England where they were presented to curious audiences. But how they and other Papuans might have perceived the encounters with European photographers in New Guinea must be inferred from the writings and images produced by Lindt and others at the time, as well as from an understanding of the surrounding contexts. In approaching the question of how Papuans might have perceived the photographic encounters with Lindt, it is worth considering Felix Driver's suggestion that the process of imaging places such as New Guinea might best be conceived of 'in terms of transactions rather than projections'. ${ }^{16}$ While Driver analyses sketches, approaching the photographic encounter as a 'transaction' or an exchange, in which all parties are invested to varying degrees, opens the way for understanding the process of the individual photograph's production as 'negotiated in various ways'. ${ }^{17}$ This can lead to the uncovering of indigenous agency in the photographic encounter and in encounters more generally. Some evidence for the negotiations involved in Lindt's photographs are provided by Lindt himself, both in the text in Picturesque New Guinea as well as in some of the images.

Lindt introduces the sections in his book where he writes about his photographic sojourns in the villages of south-east New Guinea in a casual manner - he always 'sallies' forth to photograph - but he clearly relied on carriers, interpreters and assistants in order to carry and set up his bulky and heavy equipment and to get subjects to pose for his camera. ${ }^{18}$ What is interesting in Lindt's book is that he frequently mentions the aid he received, and he also photographed these helpers. For example, in a campsite scene photographed by Lindt on his first inland trek, at Badeba Creek, the Papuan carriers/guides/interpreters can be seen resting alongside the two European explorers in the image (Figure 9.1). These carriers and helpers were not always local or, indeed, Papuan. The explorer H.O. Forbes employed Malay servants and Amboynese hunters for his expeditions and Lindt writes that Forbes spoke to him 'very highly of these dusky retainers as being faithful and affectionate', and then notes, 'This testimony I am able to corroborate from my own experience; I have found both the Malays and the Sundanese as servants industrious and obedient. ${ }^{19}$ Despite the omission of names, the mere mentioning of this help received from Papuans, Malays and others, and Lindt's photographing of these men, is remarkable, as local help was seldom acknowledged in early travelogues in order to magnify the heroism and bravery of the male European 'hero-explorer' ${ }^{20}$

16 Driver 2004: 3.

17 Driver 2004: 3.

18 Lindt 1887: 30

19 Lindt 1887: 20.

20 Driver and Jones 2009: 11. 


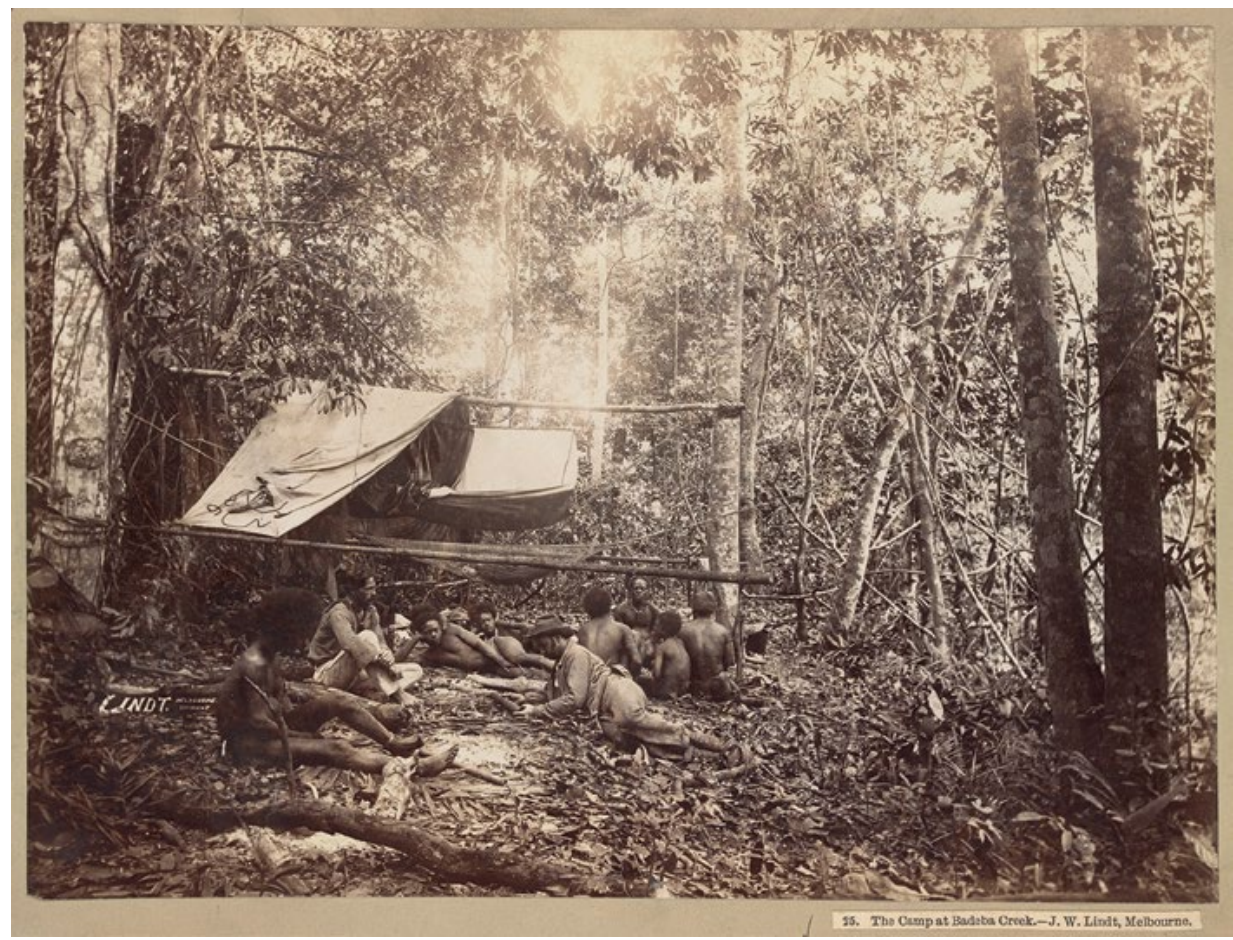

Figure 9.1 J.W. Lindt, 'The Camp at Badeba Creek', 1885.

Albumen silver, $15 \times 20.5 \mathrm{~cm}$.

Source: 'Picturesque New Guinea', vol. 2, acc. no. H42424, plate 25, Pictures Collection, State Library of Victoria, Melbourne.

What is clear from Lindt's narrative in Picturesque New Guinea is that when these helpers were not present, the exchanges and encounters with the local villagers were often awkward and drawn out. In many cases, the European expedition members had to use gestures and mime in order to acquire information from the locals and to get their cooperation in posing for Lindt's camera. On Heath Island, Lindt recounts in detail how he and Mr Smart (a conchologist) were reduced to acting out a cannibal feast, with Mr Smart as the main course, in order to ascertain whether some 'flagged places' they came across were associated with cannibalism. ${ }^{21}$ In another instance, in Kamali village, Lindt writes how he decided to stay on longer than the other expedition members, due to it being 'more attractive than the village we had just quitted', and while at first he had misgivings about getting sitters, to Lindt's astonishment all the inhabitants eventually turned out, and he writes that this was 'evidently with the object of being photographed'. ${ }^{22}$ What this episode makes clear is that the Papuans of the south-east coast were often willing, though also at times hesitant, participants in the photographic encounter. 
Even with the help of interpreters, Lindt sometimes struggled or did not get to take the photographs he wanted. In Moapa, for instance, he set about attempting to photograph a ceremonial structure in the centre of the village that had ornamented human skulls hanging from it. However, due to the strong wind blowing that day he was concerned the skulls would be reduced to blurred traces on the negative. Lindt writes that he offered 'almost any price (in tobacco) to induce the natives to go up and steady the skulls while the picture was being taken', but he was ultimately unable to convince them and was reluctantly 'compelled to trust to the pen, unaided by the camera' ${ }^{23}$ In Kapa Kapa, where Lindt met a couple in mourning for their three children, he found it took 'a good deal of persuasion' by their interpreter to get them to pose in a group portrait for him. ${ }^{24}$ What these encounters, or failed encounters, in Moapa and Kapa Kapa make clear is that the Papuans Lindt wanted to photograph sometimes refused to participate. Paradoxically, then, it is the absence of certain scenes in the photographic record that speaks volumes in terms of indigenous agency in many early encounters.

The tactless incidents in Moapa and Kapa Kapa aside, Lindt was aware of etiquette and clearly had been briefed on how to behave in certain situations in order to ensure the goodwill of the Papuans - this, of course, being due to the fact he was connected with an official expedition sent out to New Guinea to establish and maintain good relations with the indigenous islanders. On one occasion ,Lindt writes that he would never enter a dwelling without first obtaining the owner's permission, it being 'absolutely necessary to observe a certain amount of etiquette to avoid giving offense' ${ }^{25}$ In another display of his adherence to local customs and rules of etiquette, Lindt participated in a local ceremony in Sadara Makara, a Koiari village inland from Port Moresby. After shaking hands with one of the chiefs, Lohio-bada, Lindt was invited to exchange names with him and was thereby given the name Misi Lolo (meaning 'maker of pictures' in the Koiari language). ${ }^{26}$ This display of goodwill and willingness to participate in local traditions no doubt helped Lindt obtain subjects for his photographs the following day, when he 'sallied' into the village with his camera:

The native population, men, women, and children, gathered round Misi Lolo with a childlike curiosity to watch my proceedings, and readily obeyed all instructions. They stood in groups, took the proper attitudes, and even posed picturesquely, as conscious that they were being immortalized in picture. ${ }^{27}$

23 Lindt 1887: 75.

24 Lindt 1887: 60-61.

25 Lindt 1887: 87.

26 Lindt 1887: 40 .

27 Lindt 1887: 44. 
Aside from the fact Lindt had been introduced to the Koiari people the previous day as 'an artist who had come to take pictures of the village', and also that he came to New Guinea in the company of the 'Great White Chief' (as Sir Peter Scratchley was introduced to many Papuans), ${ }^{28}$ there was another factor that likely contributed to this 'easy' and automatic performance of the photographic encounter: the mediating presence of the LMS missionary, Reverend William G. Lawes.

\section{Missionary as mediator}

Reverend Lawes and his camera were well known to the residents of the villages in the Port Moresby mission district as Lawes had been working in this region of New Guinea since 1874. In his memoir of his time spent living and working in New Guinea, the natural history collector Andrew Goldie recounts that Lawes's name was 'sufficient as a passport'. ${ }^{29}$ By simply shouting 'Misi Lao' (as Lawes was called by the Papuans) the guides who accompanied Lawes on his regular tours of the territory surrounding Port Moresby would warn their 'countrymen of the arrival of Mr Lawes and thus the intelligence was carried from mountain to mountain'. ${ }^{30}$ Though Lawes did not accompany the expedition to Sadara Makara, the Koiari people knew what was expected of them in front of the camera as a result of his earlier visits and readily assumed the poses Lindt suggested. What Lindt witnessed was a 'scripted' performance.

This performance for the photographer was also likely prompted by the fact that Lindt's expedition party had with it tobacco and tomahawks for trading and payment. For many Papuans, being party to the 'performance of [the photograph's] creation' ${ }^{31}$ was a curiosity, and sitters frequently benefitted in material terms. As Helen Gardner and Jude Philp note in relation to Reverend George Brown's photographic practices on New Britain, the subjects of his photographs were often paid with trade goods in order to sit still before the missionary's camera. ${ }^{32}$ Frequently there are signs of this practice in missionaries' and other travellers' photographs from the Pacific. For example, a subject might be holding the knife, tomahawk, or tobacco given them for their time and cooperation. Tobacco was widely used as an item of trade in the Pacific, and it is known that Lawes was a major importer to New Guinea. ${ }^{33}$

\footnotetext{
Lindt 1887: 40.

Goldie 2012: 72.

Goldie 2012: 72 .

Gardner and Philp 2006: 190.

Gardner and Philp 2006: 178.

Hays 1991: 96, 98.
} 
The mission station in Port Moresby was the first port of call for many European visitors who came to New Guinea. In the early years of the mission, Lawes played host to the occasional exploration party led by scientists such as the ethnographer Octavius C. Stone, but by the late 1870s the number of arrivals drastically increased. This was a result of the short-lived gold rush on the Laloki River in 1878 and the increasing interest aroused in Australia around the question of annexation. As Robert Holden writes, the annexation of New Guinea fuelled 'Australia-wide feelings of common interests and shared responsibility', ${ }^{34}$ and in 1883 the Age and Argus newspapers dispatched journalists to report on the state of the land and its people following the ultimately unsanctioned annexation by Queensland of the south-eastern part of the island..$^{35}$ Lawes was an important intermediary for these men, as well as for the collectors, ethnographers and botanists who visited Port Moresby, as he knew the land and its people, and could speak the Motu language. However, he did not approve of the new 'breed' of explorer to land on New Guinea shores in 1883. In a letter to the LMS secretary, Lawes does not hide his contempt and writes:

We have two parties of white men here at present representing two Melbourne papers, the 'Argus' and 'Age'. They are here for exploration or rather perhaps to make interesting letters for their papers - one we know, descriptive of country, was written and sent before they arrived here, or had even set a foot on New Guinea. ${ }^{36}$

When it was finally decided that the territory would officially become a British protectorate, Lawes declared 'Almost anything ... will be better than leaving the people and their lands at the mercy of lawless men and mad adventurers' ${ }^{37}$ Sir Peter Scratchley, sent to New Guinea in 1885 to establish good relations with the Papuans, was therefore a welcome guest.

As a missionary working for the LMS, Lawes did not have much time or money to spend on personal pastimes. While mission societies understood the power of pictures in mission work, there is no indication in the correspondence between Lawes and the LMS secretary that he was expected to supply photographs for them or that he was compensated for the cost of his photographic equipment and supplies. Indeed, Lawes threatened to leave the mission on a number of occasions, writing that the stipend he received 'never has been enough' to make ends meet. ${ }^{38}$ Lawes therefore photographed the New Guinea villages, landscapes and people when the opportunity arose. The arrival of Sir Peter Scratchley's official expedition, with the professional photographer on board, presented just such an opportunity.

34 Holden 1988: 27.

35 See Souter 1963: 49-56.

36 Lawes to W. Whitehouse, 23 July 1883, p. 4, microform M93 LMS Papua Letters, National Library of Australia [hereafter NLA].

37 Lawes to Rev. R.W. Thompson, 30 October 1884, p. 2, microform M93 LMS Papua Letters, NLA.

38 Lawes to Rev. R.W. Thompson, 12 February 1884, p. 3, microform M93 LMS Papua Letters, NLA. See also 


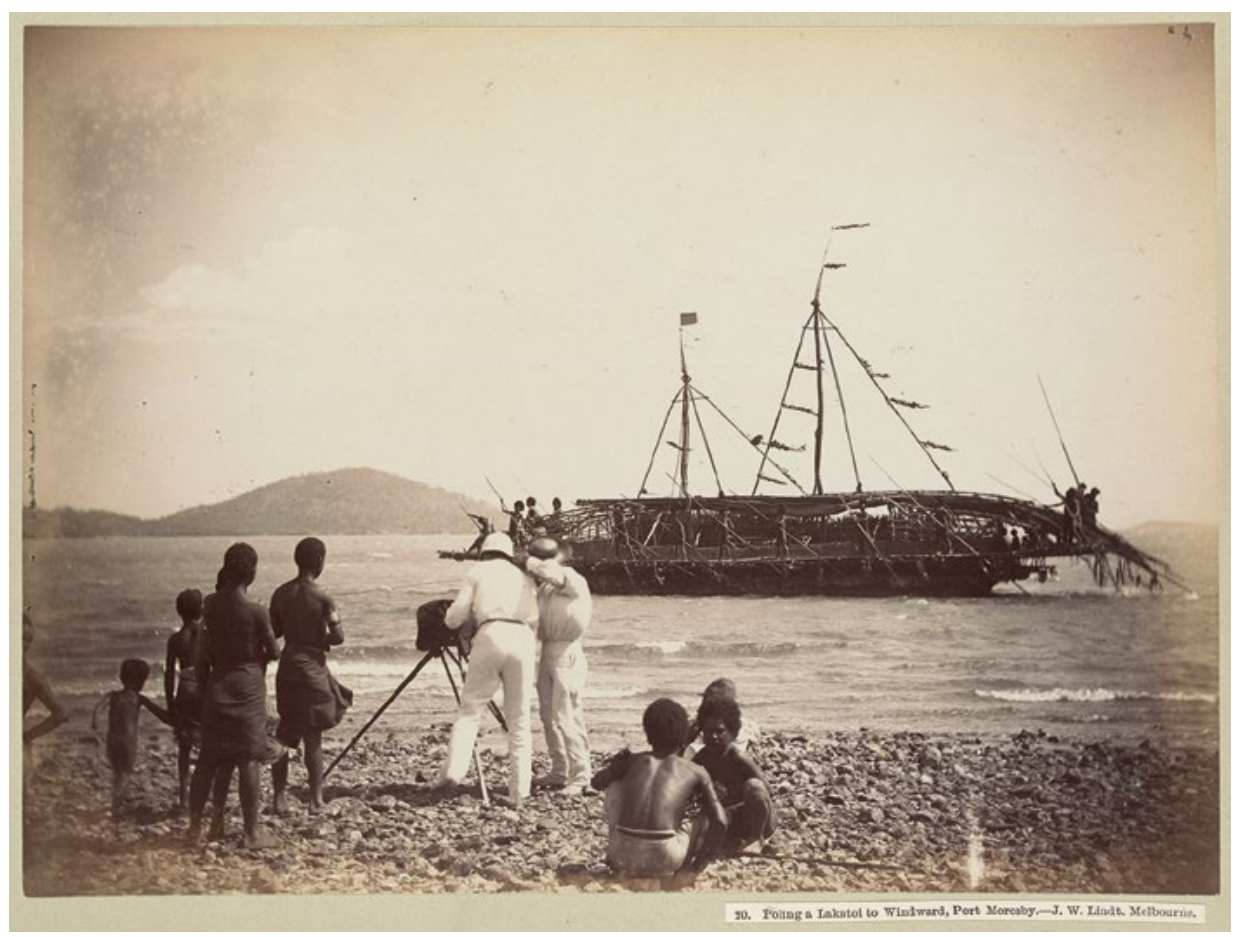

Figure 9.2 J.W. Lindt, ‘Poling a Lakatoi to Windward, Port Moresby', 1885.

Albumen silver, $15 \times 20.5 \mathrm{~cm}$.

Source: 'Picturesque New Guinea', vol. 1, acc. no. H42423, plate 20, Pictures Collection, State Library of Victoria, Melbourne.

The photographic encounter between Lawes and Lindt resulted in a number of duplicates (or very similar subjects from slightly different angles) in the two men's photographic oeuvres. For example, their images of H.O. Forbes's expedition party setting out on an inland trek and the lakatoi (large Motu trading canoes) in the harbour of Port Moresby preparing for the annual westward voyage to trade the local pottery for sago and other products. In Lindt's lakatoi photograph, Lawes can be seen in the foreground of the image composing or exposing a photograph of a large lakatoi with another man assisting him or looking on (Figure 9.2), while in the photograph of Forbes's expedition party he is standing to the right of the image with three other European men (Figure 9.3). ${ }^{39}$ It is not difficult to imagine that

39 Lawes's photographs of these scenes are in an album held at the School of Oriental and African Studies (SOAS) in London (CWM/LMS/Papua New Guinea/Photographs/Box 1, file 1). His New Guinea photographs are as widely dispersed as Lindt's, owing to the fact he gave, or most likely sold, a large selection of his negatives to the Sydney-based professional photographer Henry King in c. 1890-93. There is an album of Lawes's photographs compiled by King in the Mitchell Library in Sydney (PXE 720), and two further albums, as well as loose prints, are held in London at SOAS (CWM/LMS/Papua New Guinea/Photographs/Box 1, file 1; CWM/ LMS/Papua New Guinea/Photographs/Box 3, file 4). The University of Southern California Library has digitised 130 Lawes prints held at SOAS and these are available to view online at digitallibrary.usc.edu. Further prints of Lawes's New Guinea pictures are held in collections in Australia, the UK, New Zealand, the USA and Germany. 
Lawes enjoyed discussing the work of the expedition party as well as Lindt's work on these occasions, and he did not let the opportunity to photograph alongside the professional photographer pass him by. Virginia-Lee Webb has termed this phenomenon the 'tourist effect', which occurs when individuals in a group gather or line up to photograph the same scene, event or monument, for example - an experience familiar to many travellers today. ${ }^{40}$ Lindt also took several photographs of the local Motu 'water carriers' during his time in Port Moresby, as did Lawes, and when Reverend Brown visited Port Moresby in 1890 it seems Lawes took him to photograph these women as well. ${ }^{41}$ Perhaps Brown wanted to capture his own version of the subject made famous by Lindt five years earlier.

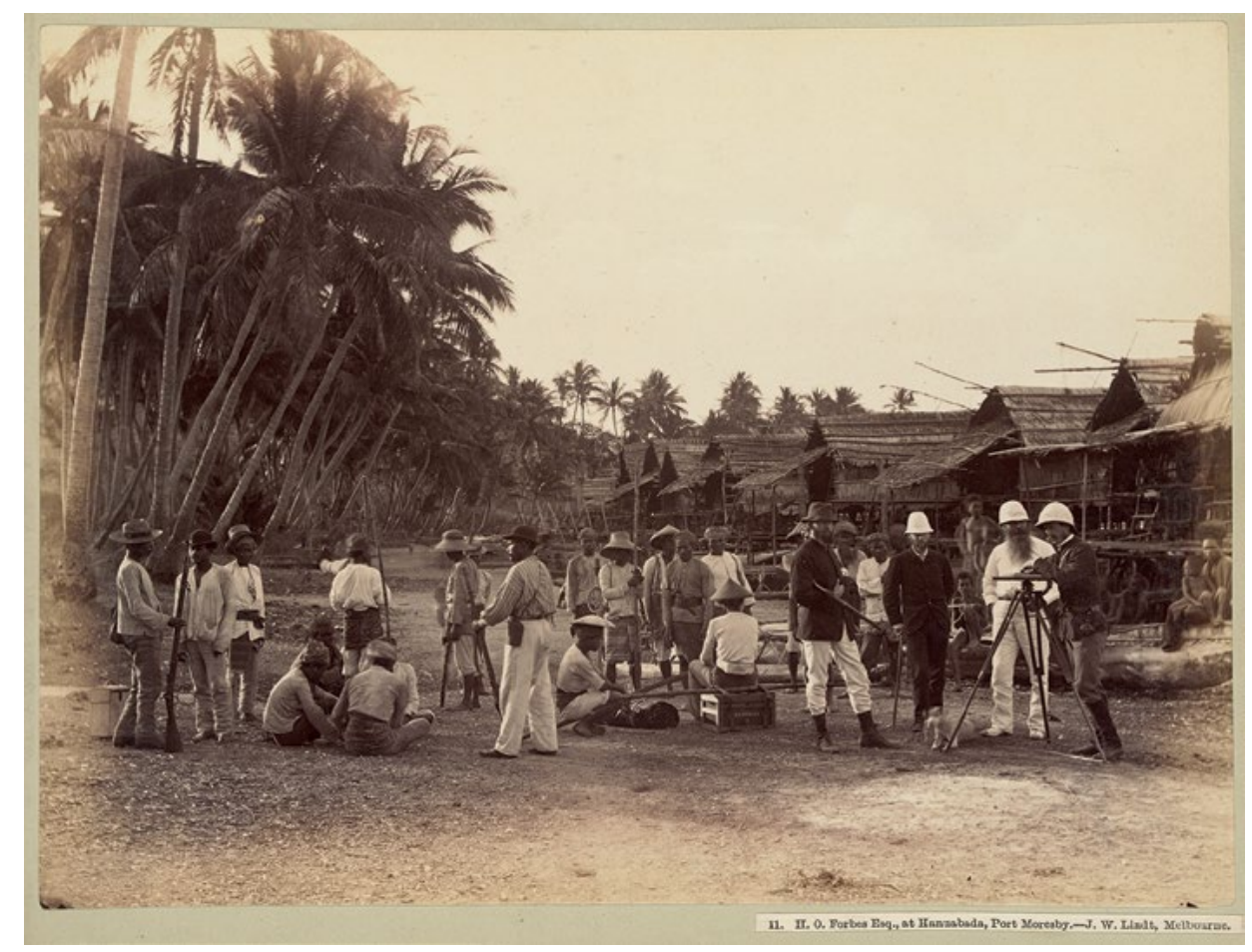

Figure 9.3 J.W. Lindt, 'H. O. Forbes Esq., at Hanuabada, Port Moresby', 1885.

Albumen silver, $15 \times 20.5 \mathrm{~cm}$.

Source: 'Picturesque New Guinea', vol. 1, acc. no. H42423, plate 11, Pictures Collection, State Library of Victoria, Melbourne.

40 Webb 2006: 60.

41 Rev. Brown's photograph of the Motu 'water carriers' is in an album of his New Guinea views held in the Mitchell Library at the State Library of New South Wales (Album of Papua New Guinea, Rev. George Brown, ca. 1890-1905, PXA 925, Mitchell Library, State Library of New South Wales, Sydney). 


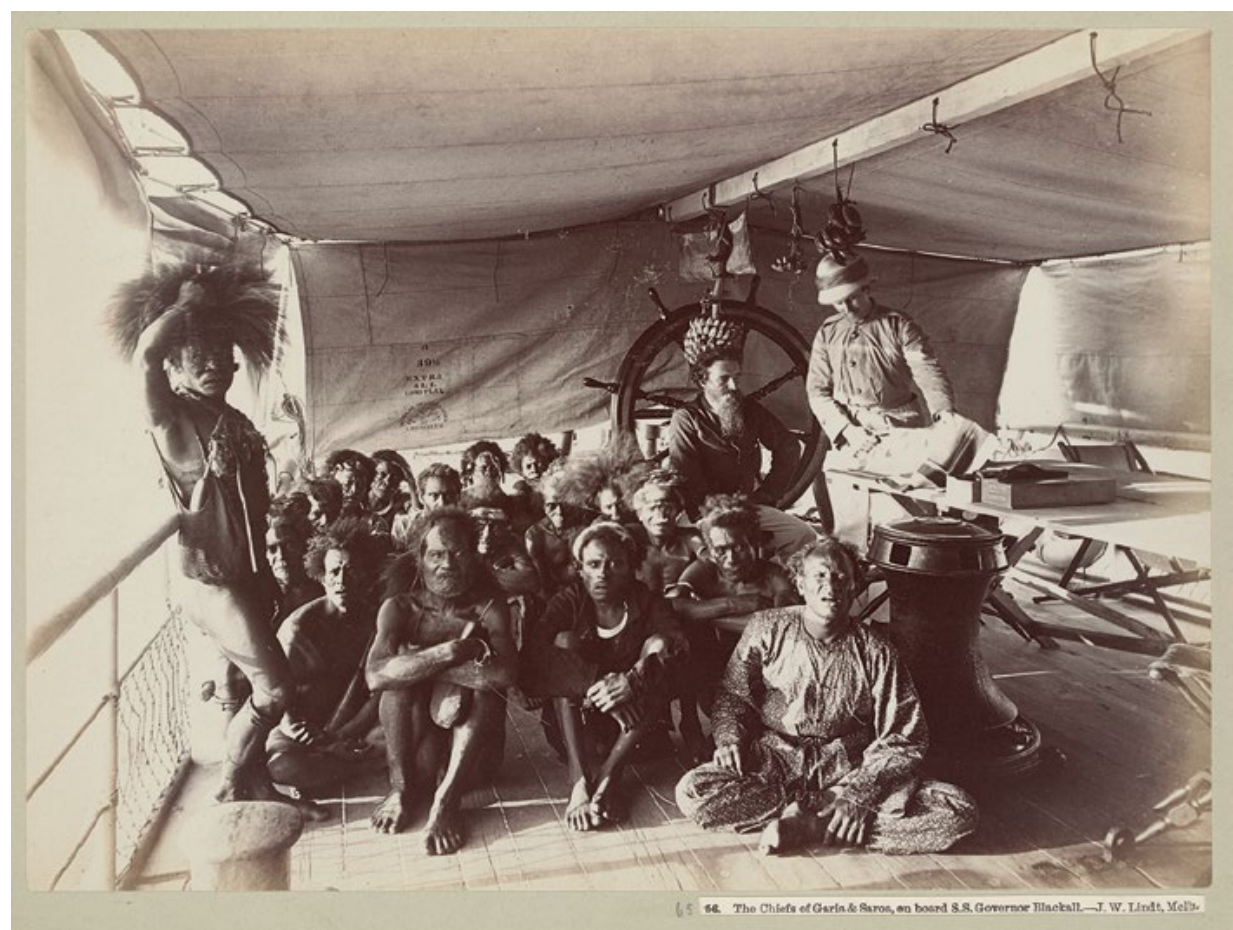

Figure 9.4 J.W. Lindt, 'The Chiefs of Garia \& Saroa, on board S.S. Governor Blackall', 1885.

Albumen silver, $15 \times 20.5 \mathrm{~cm}$.

Source: 'Picturesque New Guinea', vol. 3, acc. no. H42425, plate 65, Pictures Collection, State Library of Victoria, Melbourne.

Lawes was not the only European to play host to the Special Commissioner and the expedition party during their time in New Guinea. The Reverend James Chalmers, who had worked alongside Lawes since 1877, also acted as host, guide and interpreter for the expedition on its southward journey along the coast. Lindt captured him in a photograph of an assemblage of chiefs from the villages of Garia and Saroa who had been invited on board the Governor Blackall to receive gifts in exchange for ceasing aggressions against the village of Kaele (Figure 9.4). The image is mentioned by Lindt in his narrative and he writes that these men presented 'perhaps the most curious human group ever assembled on the deck of a steamer, the chiefs making no objection, although none of them had ever seen a camera before, and they probably supposed the proceeding to be some mystical rite preliminary to the negotiations' ${ }^{42}$ Whether the claim that the chiefs had never seen a camera is true or not, by recounting the encounter 
in this way, Lindt underscores the importance of the task he was employed to undertake during the expedition while at the same time adding a further layer of meaning and interest to the image.

\section{The camera as historical actor}

Photography in the nineteenth century was a mechanical, chemical, social and cultural process. Unlike most photography today, taking a photograph in the late nineteenth century was not a simple or quick undertaking. More often than not, the cameras used were large and cumbersome objects. As Susan Sontag writes, 'Picture-taking is an event in itself', ${ }^{43}$ and when Lindt and others photographed south-east New Guinea it was, in fact, more a case of making photographs than taking them. The word 'taking' implies little effort on the photographer's part other than exposing the negative. We know the equipment Lindt used in New Guinea due to the sales catalogue he compiled in 1888 in which he makes special mention of the lenses employed for his 'Picturesque New Guinea' series. Lindt took six lenses with him on the expedition, all of which fitted the flange of his whole-plate camera, thereby giving him 'a wonderful facility of securing almost any kind of subject' ${ }^{44}$ The camera itself, though Lindt does not describe it, would have been made of wood and, as it could hold whole glassplate negatives, was a conspicuous and cumbersome apparatus needing time and effort to transport and set up.

Lindt had the luxury of a darkroom on board the Governor Blackall, which meant he did not have to develop his glass negatives in the field. By 1885 he was also using gelatin dry plates - a much easier process than the wet and dry collodion plates he had used up until $1880 .{ }^{45}$ However, he did not have the equipment or comforts of his Melbourne studio on hand and had to make do with whatever makeshift facilities he could rig up in order to change and store away the exposed plates. In one instance, Lindt stole away to the hut that was his accommodation for the night and used a lamp covered in red cloth, all the while hoping there would be no interruptions by the curious 'natives' ${ }^{46} \mathrm{He}$ also had to transport his camera, lenses and glass-plate negatives whenever he ventured out to photograph in the villages and surrounding areas, or rather the hired carriers would transport these for him. In his narrative, Lindt writes that 'the impedimenta required for even a few nights of camping [are] both bulky and heavy' and he had great difficulty making up 'portable packages for the

43 Sontag 1979: 11.

44 Lindt 1888: 44.

45 Jones 1985: 8.

46 Lindt 1887: 43. 
native carriers' ${ }^{47}$ When the expedition party finally reached the village, often after many hours of walking over steep or uneven terrain and after several river crossings, subjects had to be scouted out and, in the case of human subjects, convinced to sit for the photographer. Some may not have seen a camera before, or been photographed, and part of the photographer's and/or interpreter's task was to persuade them to take part. Once posed in front of the camera the negotiations that ensued were frequently dictated by the technology - most notably, the need to sit or stand still due to the sometimes long exposure times. In the case of Lindt's photograph of the Garia and Saroa chiefs, the subjects were brought to him and the camera was another novelty in an already alien situation. However, the chiefs still had to be active participants in the encounter in order to ensure that the resulting image was a success. The photographic encounter between Lindt and the chiefs was therefore a collaborative undertaking: the Papuans 'watched' and 'obeyed' while Lindt prepared the equipment and instructed them.

Critical reflections on the camera's materiality and impact in colonial encounters have drawn attention to its cumbersomeness for the early outdoor photographers and its equation with disease, colonial guns and European aggression in 'first' encounters. ${ }^{48}$ Early encounters in the Port Moresby mission district were occasionally shaped by an element of fear, as some Papuans believed the camera was an object imbued with deadly or harmful powers. However, investigating beyond the Papuans' initial responses to the camera reveals the extent of the technology's influence on encounters in New Guinea. While visiting the village of Boera in January 1876, Lawes found he was able to take photographs of the teacher's house and the village unhindered, but on attempting to take some of the people 'they were afraid that it would cause their death!' ${ }^{49}$ This early encounter between Lawes and the people of Boera influenced his approach to photographing and he subsequently changed his method of working. In a journal entry written on 9 August 1877, Lawes notes,

I want to get some [views] of the natives but must disarm their suspicion first or they will think as the natives at Boera that the camera is a disease-making machine. I have shown them those I have printed of Anuapata and the natives and they are greatly taken with them. ${ }^{50}$

47 Lindt 1887: 30.

48 See, for example, Morris 2009: 1; Ryan 1997: 143-144; Sandweiss 2002: 223.

49 Lawes, journal entry, 12 January 1876, microfilm CY292, Mitchell Library, State Library of New South Wales [hereafter ML].

50 Lawes, journal entry, 9 August 1877, microfilm CY292, ML. 
To what extent this is Lawes projecting his experience at Boera onto the Papuans in question is unclear, but this is an interesting episode as it highlights the different responses that cameras and photographs could elicit. It also illustrates the way in which Lawes consciously used photographs in his interactions with Papuans as a result of earlier reactions to the camera.

That the photographic encounter in New Guinea in the late nineteenth century was often not a spontaneous or natural encounter is further evidenced by the positioning of several of the human subjects in Lindt's photographs. The problems presented by long exposure times meant that several of his subjects are posed in an almost regimented manner. Indeed, in several of Lindt's images containing large groups of Papuans the people are seated, which supposedly was the pose in which they were less likely to move and thereby ruin the shot. Lawes also reported on the problems associated with long exposure times and recounts one instance in a diary entry for November 1877 that occurred in the village of Kerepuna:

Took a few photographs today of houses and some of the natives yesterday and today. The people are anxious to be taken, but many of them can't remember to sit still, will turn around to speak to someone when the plate is half exposed and so on. ${ }^{51}$

The experience of being photographed was a curiosity to the people of Kerepuna and by acquiescing to their requests Lawes was engaging in a similar transaction to those of the Reverend Brown, who, as Gardner and Philp note, 'used the making of a photograph to form relationships with local people'.$^{52}$ As mentioned above, Lawes even took photographs back to the villages in which they were taken and reported that the local people of his district were 'very much interested in the photographs', and that chiefs would approach him to have their portraits taken. ${ }^{53}$

The regimenting of Papuan bodies, which takes its most extreme form in the anthropometric and type portraits done by several visitors to the region, was therefore also often dictated by the demands of the technology rather than solely by current trends in science. Lawes took many such portraits in the makeshift studio he set up at the mission house in Port Moresby, and while Lindt had intended to take such 'head shots' as well, his efforts were thwarted by the strong trade winds that blew him and his 'studio' across the porch. ${ }^{54}$ Such portraits pose the most complex and interesting set of questions, as they

\footnotetext{
51 Lawes, journal entry, 29 November 1877, microfilm CY292, ML.

52 Gardner and Philp 2006: 178 .

53 Lawes, journal entry, 10 August 1877, microfilm CY292, ML; Lawes, journal entry, 13 August 1877, microfilm CY292, ML.

54 Lindt 1887: 55-56.
} 
encapsulate the distance in the photographic encounter. They produce a sense of unease in most viewers today - a cultural unease stimulated by our knowledge of the photographer's intentions and the ultimate use to which such photographs were put. We can assume that in the case of Lawes and Lindt their intentions were related to recording racial differences and otherness; but the minds of the subjects, their motivations, thoughts and feelings are less clear. How might these encounters have been perceived by the portrait sitters as they were seated against a white-sheet backdrop outside the mission house in Port Moresby, instructed to turn one way, then the other, and to hold still, the camera almost 'pinning' them to the spot? For those who were used to Lawes and his camera this may have seemed an extension of his in situ photography in their villages. But what of those who came from villages further afield, where there was no mission station or teacher? Did they enjoy the experience or feel pressured into it? Such questions are difficult or, indeed, impossible to answer, but they are important questions if we want to begin approaching the nuances of such photographic encounters.

\section{Conclusion}

That the local Papuans frequently determined the nature of the photographic encounter is evidenced in certain episodes in the text Lindt wrote for his book, as well as in images from his series that record the guides and/or interpreters who accompanied him. While Lindt may have framed his narrative in such a way as to place himself centre stage as the explorer-artist-photographer 'sallying forth' to photograph the people and exotic landscapes of New Guinea - he nevertheless notes the vital assistance given to him by Papuan guides and interpreters, as well as European interpreters, Polynesian teachers working for the LMS, and traders with knowledge of the local people and their culture. One European, in particular, may be said to have directly influenced several of Lindt's encounters - the LMS missionary, Reverend Lawes - and by placing the photographic outputs of these two men side by side, more searching questions can be asked about the nature of each man's encounters with the Papuans of south-east New Guinea. Finally, focusing on photography as a technological and social process allows a space to be opened up in which the local people can be seen to act in, and impact on, this particular form of exchange - what becomes clear is that the photographic encounter was not, and seldom is, one-sided. 
INDIGENOUS INTERMEDIARIES

\section{References}

Barker, Geoffrey 2010, 'Refracted Vision: Nineteenth-Century Photography in the Pacific', Master's thesis, University of Sydney.

Barringer, Tim 1998, 'The South Kensington Museum and the colonial object', in Colonialism and the Object: Empire, Material Culture and the Museum, Tim Barringer and Tom Flynn (eds), Routledge, London and New York, 11-27.

Cato, Jack 1952, 'The Great Lindt', The Australasian Photo-Review, July: 396-497.

-1955, The Story of the Camera in Australia, Institute of Australian Photography, Melbourne.

Driver, Felix 2004, 'Imagining the tropics: views and visions of the tropical world', Singapore Journal of Tropical Geography 25(1): 1-17.

Driver, Felix and Lowri Jones 2009, Hidden Histories of Exploration: Researching the RGS-IBG Collections, exhibition catalogue, Royal Holloway, University of London, in association with the Royal Geographical Society, London.

Gardner, Helen and Jude Philp 2006, 'Photography and Christian mission: George Brown's images of the New Britain Mission 1875-80', The Journal of Pacific History 41(2): 175-190.

Goldie, Andrew 2012, 'Andrew Goldie's memoir: 1875-1879', reprinted in Memoirs of the Queensland Museum Culture, vol. 6, Clive Moore, Steve Mullins (eds), Queensland Museum, Brisbane, 39-127.

Hays, Terence E. 1991, "No tobacco, no hallelujah": missions and the early history of tobacco in Eastern Papua', Pacific Studies 14(4): 91-112.

Holden, Robert 1988, Photography in Colonial Australia: The Mechanical Eye and the Illustrated Book, Hordern House, Sydney.

Jones, Shar 1985, J. W. Lindt: Master Photographer, Currey O'Neil Ross Pty Ltd, South Yarra, Victoria.

Lindt, J.W. 1883, A Few Results of Modern Photography, Welch \& Whitelaw, Melbourne.

_1887, Picturesque New Guinea, Longman, Greens and Co., London.

1888, A Few Notes on Modern Photography, McCarron, Bird and Co., Printers, Melbourne. 
Morris, Rosalind C. 2009, 'Introduction', in Photographies East: The Camera and Its Histories in East and Southeast Asia, Duke University Press, Durham, NC, and London.

Newton, Gael 1988, Shades of Light: Photography and Australia 1839-1988, Australian National Gallery, Collins Australia with assistance from Kodak, Sydney.

Orchard, Ken 1999, 'J. W. Lindt's Australian Aboriginals (1873-74)', History of Photography 23(2): 163-170.

Poignant, Roslyn 1992, 'Surveying the field of view: the making of the RAI photographic collection', in Anthropology and Photography 1860-1920, Elizabeth Edwards (ed.), Yale University Press in association with The Royal Anthropological Institute, London, New Haven and London, 42-73.

Quanchi, Max 2007, Photographing Papua: Representation, Colonial Encounters and Imaging in the Public Domain, Cambridge Scholars Publishing, Newcastle.

Quartermaine, Peter 1992, 'Johannes Lindt: photographer of Australia and New Guinea', in Representing Others: White Views of Indigenous Peoples, Mick Gidley (ed.), University of Exeter Press, Exeter.

Ryan, James R. 1997, Picturing Empire: Photography and the Visualization of the British Empire, University of Chicago Press, Chicago.

Sandweiss, Martha A. 2002, Print the Legend: Photography and the American West, Yale University Press, New Haven and London.

Sontag, Susan 1979, On Photography, Penguin Books, London.

Souter, Gavin 1963, New Guinea: The Last Unknown, Angus and Robertson, Sydney.

Webb, Virginia-Lee 2006, 'In situ: photographs of art in the Papuan Gulf', in Coaxing the Spirits to Dance: Art and Society in the Papuan Gulf of New Guinea, Robert L. Welsch, Virginia-Lee Webb, Sebastian Haraha, exhibition catalogue, Hood Museum of Art, Dartmouth College, Hanover.

Willis, Anne-Marie 1988, Picturing Australia: A History of Photography, Angus and Robertson Publishers, North Ryde, NSW, and London. 
This text is taken from Indigenous Intermediaries: New Perspectives on Exploration Archives, edited by Shino Konishi, Maria Nugent and Tiffany Shellam, published 2015 by ANU Press, The Australian National University, Canberra, Australia. 